being in the deep soundings between the islands of St. Thomas and Ste. Croix.

During the same day two other slight shocks, one at about Io A. M. the other at noon, were felt at St. Thomas; they were unaccompanied by noise.

St. Thomas, W. I., March 2I

\section{Physical Axioms}

CONVINCED that the fulfilment of astronomic predictions can never demonstrate the laws of motion, and yet feeling myself quite destitute of intuitive belief in those laws, I have been led to think that in the present controversy truth may lie somewhere between the positions respectively enunciated by $M r$. Spencer and his critic.

By reasoning which seems to me equally lucid, ingenious, and unanswerable, Mr. Spencer has shown that certain ultimate mechanical laws are tacitly assumed in every process of experimental verification. But I do not see that this vitiates completely the inference drawn from such verifications The pure empiricists argue that because certain observed results coincide with the results of calculation, therefore the assumptions on which the calculation was based must be true. Now without doubt the demonstrative character of this inference vanishes entirely under Mr. Spencer's searching criticism. But it seems to me that a high probability remains behind. For were there any but an excessively minute error in the laws of motion, our astronomical observations could agree with the results of calculation only by a conflict of errors-a conflict which Mr. Spencer himself hints at. But there are overwhelming chances that these errors would not be so accurately adjusted throughout an immense variety of cases as exactly to compensate one another in every single instance. Hence I cannot but regard the laws of motion as hypotheses, the truth of which is shown by experiment to be overwhelmingly probable. The dortrine here assumed may be illustrated by an appeal to those old friends of probability students - the dice. If I throw double sixes ten times running I naturally conclude that the dice are loaded. This supposition almost necessarily involves the sameness of the ten throws, whereas the supposition that they were not loaded is consistent with an immense number of other results. Our minds choose the former alternative in obedience to an instinct which might with much show of propriety be formulated into an axiom. We may, however, deduce a ju-tification for it from two ultimate intuitions of our nature-belief in uniformity of sequence and the general doctrine of chances--intuitions by which the mind apprehends respectively the ultimate law of knowledge and the ultimate law of ignorance. Belief in any special tact beyond individual experience can be rationally arrived at only by applying the former law to that knowledge which our individual experience furnishes, and the latter law to that ignorance which our individual experience has failed to enlighten.

It is the approximate truth of the laws of motion to which I have throughout referred. That there may be an excessively minute error in all physical and even all geometrical principles, Prof Clifford has long ago shown how unphilosophical it is to deny.

Royal College of Chemistry, April i 8

$$
\text { F. W. FRANKLAND }
$$

\section{The Fertilisation of Fumariacex}

Apropos of the interesting discussion on this subject which has appeared in your columns, I should much like to know whether any of your readers have observed the mode of fertilisation in Corydalis claviculata. Last summer I spent a considerable time in attempting to find this out, but without success. In every flower which I gathered in the mature state, I found the style broken off at the articulation immediately above the oviry, as if to prevent the possibility of fertilisation after a certain period. As the interior parts are completely concealed by the corolla, it was difficult to determine whether the separation had actually taken place on the flower, or was the result of the dissection, but I believe the former to be the case. In a large number of observations, extending over a considerable time, I never saw an insect visit the plant (this was in Westmoreland), though seeds were freely produced. Müller does not mention this species in his classical work on the subject, "Die Befruchtung der Blumen durch Insekten." ALFRED W. BENNE'TT

ALLOW me to bring before the notice of readers of NATURE a small point bearing on the fact of the bright hue presented, after fertilisation, by the flowers of Fumaria catrenolata.

Is it not possible that the pale colour may be more attractive to the fertilising insects than a brighter one would be? May not the drawing-principle be the result of correlation between the art-manifestations of the attracting and the resthetic susceptibilities of the attracted organism, and not depend solely on gaudiness of the flower? If this be so, we know that these susceptibilities have, at any rate sometimes, a very limited range, as is seen in the bee-orchis, where the similarity of the labellum to the body of a bee is very close, both in colour and in form, and cannot be useless, seeing that a great amount of developmental force is expended in its production. On this view also the rejection of highly-coloured poisonous caterpillars may in part be referred to the non-agreement of their hues with the orthodox colour-notions of birds. On the other hand, if mere gaudiness is aimed at, why should there be such diversity exhibited? why would not one colour answer the purpose in every instance?

The present case is capable of ready explanation on the supposition that it comes under the influence of natural selection for, as Mr. Spencer has shown, the hue of the flower results from a diminished amount of nutritixe material supplied to the coloured parts, so that the least vigorous individuals would have these most highly coloured at the time of fertilisation. But since the pale flowers are preferred by the insects, they would stand a better chance of being fertilised than would the bright ones, so that a process of selection would be set up resulting ultimately in the disappearance of the latter.

If it be established that cross. fertilisation is not the rule with the flowers of this fumitory, of course it is a fact which has nothing whatever to do with the present argument, and the explanation given by Messrs. Darwin and Miiller is entirely satisfactory. I cannot but think, however, that special attention will bring to light many cases of cross-fertilised flowers becoming more highly coloured after fertilisation, the phenomenon being explained simply as a decomposition-phase in the life-history of the contents of the cells composing the coloured organs.

\section{S. MOORE}

I VENTURE to suggest the following as possibly an explanar tion of the fact observed by Mr. Traherne Moggridge, that the flowers of Fumaria pallidifora attain their brightest colouring when the time for their fertilisation has past.

In plants with a racemose inflorescence the individual flowers do not open simulianeously, but more or less in succession. The flowers lowest in the raceme open first: by the time they have in Funcria pallidiflos a attained their brighter colour, those a little higher up on the rachis are just at the stage for fertilisation, and the former may serve to attract insects to the latter, just as in some plants (e.g. Poinsettia) we may presume that the highly-coloured bracts attract insects to the comparatively inconspicuous flowers which they surround. The flowers a little way up the raceme would serve in their turn to attract insects to those above them; and these again to those still higher; the process going on for a considerable time in Fumaria, as it is quite common for the pedicels in the lower part of a raceme to be bearing fruit that has attained its full size, while at the top there are flower-buds still unopen.

Quisqualis indica affords another instance of flowers assuming a more intense colour after fertilisation. Its flowers grow in short spikes; on first opening and during fertilisation, are white, very faintly tinged with pink; but subsequently turn a light reddish-orange, and finally a purplish-red. T. COMBER

Newton-le-Willows, A pril 7

\section{Power of Memory in Bees}

ILLUSTRATIONS drawn from experiments or observations made upon animals lower than ourselves in the scale of life must always possess great interest. That impressions received by us in early life are more permanent than those made in after years, and that the memory of the old is less retentive in the reception of new impressions than is that of children, are circumstances universally acknowledged. On October 29, I873, I removed a hive of bees in my garden, after it was quite dark, for a distance of I2 yard from the place in which it had stood for several months; and between its original situation and the new one there was a bushy evergreen tree, so that all si ht of its former place was obstructed to a person looking from the new situation of the hive.

Notwithstanding this change, the bees, every day, flew to the locality where they formerly lived, and continued flying around the site of what had been their home, until, as night came on, they many of them sank upon the grass exhausted and chilled by the cold. Numbers, lowever, returned alive to their new position, 